\title{
Reading or listening to review summaries - which method will produce greater understanding of the key outcomes in a cochrane review?
}

\author{
Lisa Maguire ${ }^{1,2^{*}}$, Mike Clarke $^{1}$, Mark Tully ${ }^{1}$ \\ From 3rd International Clinical Trials Methodology Conference \\ Glasgow, UK. 16-17 November 2015
}

\section{Background}

Systematic reviews are key to the dissemination of the findings of clinical trials and many readers might access nothing more than a summary of these reviews. Therefore, it is essential that these summaries are clear, understandable and accessible. We explored whether readers understand key messages without having to read the full review, and if there were differences in understanding between various types of summary, including an audio podcast.

\section{Methods}

We selected four Cochrane Reviews:

-1. Workplace interventions for reducing sitting at work

- 2. Chewing gum for postoperative recovery of gastrointestinal function

- 3. Surgery for weight loss in adults

- 4. Dance movement therapy for depression

Potential participants were contacted via University and organisational mailing lists. Those who wished to take part were asked to select one of the four reviews. After answering a question about what they thought the key finding of the review would be, they were randomly assigned one of four summaries of the review: abstract, plain language summary, audio podcast or transcript of the podcast. They were asked to spend no more than 15 minutes reading or listening to the summary, before answering again the question about the key findings and to indicate whether they would now want to read the full Cochrane Review.

${ }^{1}$ Queen's University Belfast, Belfast, UK

Full list of author information is available at the end of the article

\section{Results}

This research is currently underway and final results will be presented at the conference.

\section{Conclusion}

This study repeats our previous SWAR -2 study with a new set of reviews, which suggested better understanding with the audio podcast.

Authors' details

'Queen's University Belfast, Belfast, UK. ²University of Liverpool, Liverpool, UK.

Published: 16 November 2015

doi:10.1186/1745-6215-16-S2-O2

Cite this article as: Maguire et al:: Reading or listening to review

summaries - which method will produce greater understanding of the

key outcomes in a cochrane review? Trials 2015 16(Suppl 2):O2.
Submit your next manuscript to BioMed Central and take full advantage of:

- Convenient online submission

- Thorough peer review

- No space constraints or color figure charges

- Immediate publication on acceptance

- Inclusion in PubMed, CAS, Scopus and Google Scholar

- Research which is freely available for redistribution
C Biomed Central 